\title{
Principal component analysis of steers performance and structural and nutritional characteristics of Mombasa grass
}

\author{
Antonio Leandro Chaves Gurgel ${ }^{1 *}$ (iD) Gelson dos Santos Difante ${ }^{1}$ (D) \\ Denise Baptaglin Montagner ${ }^{2}$ (D) Valeria Pacheco Batista Euclides ${ }^{2}$ (D) \\ Alexandre Romeiro de Araujo ${ }^{2}$ Juliana Caroline Santos Santana1 ${ }^{1 D}$
}

${ }^{1}$ Programa de Pós-graduação em Ciência Animal, Universidade Federal de Mato Grosso do Sul (UFMS), 79074-460, Campo Grande, MS, Brasil. E-mail: antonioleandro09@gmail.com. "Corresponding author.

${ }^{2}$ Embrapa Gado de Corte, Campo Grande, MS, Brasil.

ABSTRACT: There is little information about whether the increased secondary productivity observed in pastures fertilized with high nitrogen rates is attributable to fluctuations in the nutritional value or pasture structural characteristics, or both. This study aimed to identify a set of factors (structural and nutritional characteristics) that best explain the performance of beef steers grazing Mombasa grass pastures under residual effects of nitrogen fertilizer. The data were collected in Mombasa grass pastures fertilized with increasing rates of nitrogen ( $N$ ) (100, 200 and $\left.300 \mathrm{~kg} \mathrm{ha}^{-1}\right)$ from 2015 to 2017. In 2018, nitrogen fertilization was not used in order to characterize a residual effect of the nutrient. Variables related to pasture structural characteristics such as forage accumulation rate (FAR), canopy height, forage mass (FM) and morphological components were evaluated. The study also evaluated the nutritional value of leaf blades and the performance of beef steers based on average daily gain (ADG) and stocking rate. Principal component analysis was performed using the dataset available. Most of the variance (99.6\%) was explained by only two principal components (PCs), of which 90.0\% corresponded to PC1. The most influential parameters for $P C 1$, in order of priority, were: FAR, FM, leaf blade and stem masses. These variables were positively associated with stocking rate. Conversely, ADG was not associated with any variable. ADG was the most relevant variable for the second PC; however, this $P C$ explained less variance (9.6\%). The structural characteristics of the pasture (FAR, FM and morphological components mass) better explain the fluctuations in the performance of cattle on pastures of Mombasa grass under residual effects of nitrogen fertilizer. The stocking rate is an efficient parameter to support decision-making in managed pastures with variable stocking.

Key words: canopy structure, cattle, multivariate, nutritive value, pasture fertilization.

Análise de componentes principais entre o desempenho de novilhos de corte e as características estruturais e nutricionais do capim-mombaça

RESUMO: Há pouca informação sobre se o aumento da produtividade secundária observada em pastagens fertilizadas com altas taxas de nitrogênio é atribuível a flutuações no valor nutricional ou nas características estruturais das pastagens, ou em ambas. Objetivou-se identificar grupos de caraterísticas (estruturais e nutricionais) que melhor explicassem o desempenho de novilhos de corte em pastos de capim-mombaça sob efeito residual de doses de nitrogênio. Os dados foram coletados em pastos de capim-mombaça que receberam três doses anuais de nitrogênio (N) (100, 200 e $\left.300 \mathrm{~kg} \mathrm{ha}^{-1}\right)$ de 2015 a 2017. No ano de 2018 não foi utilizada adubação nitrogenada, para caracterizar o efeito residual do nutriente. As variáveis avaliadas foram relacionadas às características estruturais, taxa de acúmulo de forragem (TAF), altura do dossel, massa de forragem (MF) e dos componentes morfológicos. Também foi avaliado o valor nutritivo da lâmina foliar e o desempenho dos novilhos através do ganho médio diário (GMD) e da taxa de lotação. A partir do banco de dados foi realizada a análise de componentes principais. Os resultados demonstraram que 99,6\% da variação no conjunto de dados foram explicados por apenas dois componentes principais (CPS), e 90,0\% desse valor corresponde ao CP1. As características de maior magnitude para a diferenciação dos tratamentos no CP1, em ordem de prioridade foram: TAF, MF, massas de lamina foliar e de colmo. Essas variáveis estiveram positivamente associadas com a taxa de lotação. Já o GMD não se relacionou com nenhuma variável. O GMD foi a variável de maior importância para o segundo CP, entretanto, esse CP teve pouca contribuição (9,6\%) para a elucidação do resultados. As características estruturais (TAF e MF e compondes morfológicos) do pasto explicam melhor as oscilações em pastos de capim-mombaça sob efeito residual de doses de nitrogênio. A taxa de lotação é um parâmetro eficiente para apoiar a tomada de decisão em pastos manejados com lotação variável.

Palavras-chave: adubação de pastagens, bovinos, estrutura do pasto, multivariada, valor nutritivo.

\section{INTRODUCTION}

The productivity of pastures depends on both individual animal performance and stocking rate (DIFANTE et al., 2010; EUCLIDES et al., 2017). Individual performance, on the other hand, depends on the animal's genetic potential, forage quantity and quality and canopy structure (EMERENCIANO NETO et al., 2018). Nitrogen supply increases plant primary productivity (BERNARDI et al., 2018) and may change the nutritive value of the forage (CASTAGNARA et al., 2011). Quantitative 
and qualitative modifications can lead to different outcomes in animal production, for this reason it is necessary to recognize the extension of the effect of the increase in secondary productivity observed in pastures fertilized with high nitrogen rates, identifying whether its performance is limited to the greater in the fluctuation of the nutritional value or in the structural characteristics of the pasture, or both.

An effective way to validate these responses is through principal component analysis (PCA). This analysis seeks, based on a large number of original correlated characteristics, to obtain linear combinations of these characteristics, known as principal components, in such a way that the correlation between these variables is null (DA SILVA \& SBRISSIA, 2010; OLIVEIRA et al., 2019). This type of analysis has the potential to be applied in the interpretation of data on forage plants (DA SILVA \& SBRISSIA, 2010).

This multivariate statistical analysis, the PCA, allowed us to understand the simultaneous effect of the analyzed variables and to identify small variations in their use. The variance contained in each variable is expressed by Eigenvalues, which show what variables most interfere with the total variance of the set of variables. The largest Eigenvalue is associated with the first principal component, the second-largest Eigenvalue relates to the second principal component, until the smallest Eigenvalue, which is associated with the last principal component. Therefore, in PCA, the first principal component is considered as the most important element (OLIVEIRA et al., 2019).

Therefore, this study aimed to identify a set of factors that best explain the performance of beef steers grazing Mombasa grass pastures under residual effects of nitrogen fertilizer.

\section{MATERIALS AND METHODS}

The data were obtained from an experiment carried out at Embrapa Beef Cattle (located in Campo Grande - MS, latitude $20^{\circ} 27^{\prime} \mathrm{S}$ and longitude $\left.54^{\circ} 37^{\prime} \mathrm{W}\right)$. The experimental period lasted from July $11^{\text {th }}, 2017$ to May $22^{\text {nd }}, 2018$ - 196 days. According to the Köppen classification, the region has a tropical savanna climate (Aw) with a well-defined dry season from May to September. During the experimental period, the average temperature was $25.5{ }^{\circ} \mathrm{C}$ and the total rainfall reached $1108.3 \mathrm{~mm}$. The soil of the experimental area is classified as Red Latosol, with clay percentages ranging from 30 to $35 \%$ (EMBRAPA, 2013).
The pastures were sown in 2008 and 2010 with Mombasa grass (Panicum maximum cv. Mombasa) and, since then, have been grazed by beef cattle under an intermittent grazing system. The experimental area of 13.5 ha was divided into three blocks, which were divided into three modules of 1.5 ha containing six paddocks of 0.25 ha each.

The pastures were fertilized with three annual applications of nitrogen fertilizer as urea $\left(100,200\right.$ and $300 \mathrm{~kg} \mathrm{ha}^{-1}$ of $\left.\mathrm{N}\right)$ during three consecutive years $(2014 / 2015,2015 / 2016$ and 2016/2017), in addition to topdressing fertilization with $80 \mathrm{~kg} \mathrm{ha}^{-1}$ of $\mathrm{P}_{2} \mathrm{O}_{5}$ and $80 \mathrm{~kg}$ of $\mathrm{K}_{2} \mathrm{O}$. No topdress fertilizer nor nitrogen was used after the 2017 rainy season in order to characterize the residual effect of nitrogen application.

An intermittent grazing system with variable stocking rate was used. A total of 54 male Nellore animals with an initial mean live weight of $205 \pm 26 \mathrm{~kg}$ were used and remained in the paddocks throughout the experimental period. A variable number of regulator animals ( 60 animals) were used to adjust the stocking rate during the grazing period. The stocking rate was adjusted to maintain the postgrazing canopy height between $40-50 \mathrm{~cm}$, following the recommendation of EUCLIDES et al. (2015). The animals had ad libitum access to water and mineral salt during the experimental period. Thus, the evaluations on animals and pasture were monitored for six grazing cycles, totaling $54(\mathrm{~N})$ information for the variables related to animals and pasture.

Pasture evaluations were carried out in a paddock of each module at each grazing cycle in the pre-grazing condition. Pasture canopy height was measured at 40 representative points distributed in five imaginary lines per paddock using a centimeter ruler. The canopy height at each paddock corresponded to the average height of the curvature of upper leaves around the ruler (EUCLIDES et al., 2015).

Forage mass was estimated by cutting forage samples above ground level in nine $1.0 \mathrm{~m}^{2}$ squares randomly distributed in each paddock. Samples were stored in paper bags, weighed and ovendried at $55^{\circ} \mathrm{C}$ to constant weight for determination of the dry matter content (EUCLIDES et al., 2015). Three sub-samples were taken for evaluation of morphological components (leaf blade, stem and senescent material).

These components were oven-dried as previously described for estimation of the leaf blade mass, stem mass and senescent material mass. Forage accumulation rate was calculated as the difference between the current pre-grazing mass and the post- 
grazing forage mass from the previous grazing cycle (considering only the green components - leaves and stems), divided by the number of days between samplings (EUCLIDES et al., 2015).

Leaf samples were ground in a Wileymill to pass a $1-\mathrm{mm}$ mesh screen and analyzed for in vitro organic matter digestibility (IVOMD), and contents of organic matter (OM), crude protein (CP), neutral detergent fiber (NDF) and acid detergent fiber (ADF) using the near-infrared reflectance spectroscopy (NIRS). For NIRS analyses, the curves were calibrated on a Foss NIR Systems model 5000 (FOSS, Hilleroed, Denmark) using ISI WINISI II Project Manager Software V1.02 (FERNANDES et al., 2020).

Tester and regulator animals were weighed every 56 days. The stocking rate was adjusted on a weekly basis based on the post-grazing canopy height. The stocking rate was calculated as the product of the mean live weight of tester and regulator animals by the number of days they remained in the experimental module (Petersen and Lucas Junior, 1968). The average daily gain (ADG) was calculated as the difference between the final and initial live weight of tester animals divided by 196 days, expressed in $\mathrm{kg}$ / animal/day.
Before performing the principal component analysis, data were submitted to KMO (KaiserMeyer-Olkin) analysis, with a result above 0.85 . This procedure indicated that the data can be subjected to multivariate analysis. The data set was standardized to be used in the principal component analysis; therefore, each descriptor had null mean and unit variation. This analysis allowed reducing the space of the original variables into a smaller set, preserving the original data variability to the maximum. All statistical analyses were performed using software R, version 3.4.0 (R Development Core Team, 2008).

\section{RESULTS AND DISCUSSION}

The descriptive statistics of nutritional, structural and animal performance characteristics (Table 1) show that pastures under the residual effect of $300 \mathrm{~kg} \mathrm{ha}^{-1}$ of $\mathrm{N}$ were slightly superior for structural and animal performance variables. However, based on the analysis of data, variables related to nutritional value varied little between treatments.

The results of the PCA showed that most of the variance in the dataset $(99.6 \%)$ was explained by only two principal components (Table 2). The cumulative variance should be at least $70 \%$ for

Table 1 - Average, minimum (Min), maximum (Max) and standard deviation values for nutritional and structural pasture characteristics and animal performance traits.

\begin{tabular}{|c|c|c|c|c|c|c|c|}
\hline \multirow[t]{2}{*}{ Variables } & \multirow[t]{2}{*}{$\mathrm{N}$} & \multicolumn{2}{|c|}{----------100 kg ha' $\mathrm{N}$----------- } & \multicolumn{2}{|c|}{----------200 kg ha ${ }^{-1} \mathrm{~N}----------$} & \multicolumn{2}{|c|}{--------300 kg ha-1 $\mathrm{N}--------$} \\
\hline & & Average & Min - Max & Average & Min - Max & Average & Min - Max \\
\hline OM $(\%)$ & 54 & $89.9 \pm 0.7$ & $88.7-90.9$ & $90.2 \pm 0.7$ & $88.4-91.3$ & $90.3 \pm 0.7$ & $89.0-91.1$ \\
\hline $\mathrm{CP}(\%)$ & 54 & $8.8 \pm 1.0$ & $7.4-11.3$ & $9.4 \pm 1.5$ & $7.6-12.7$ & $9.6 \pm 1.3$ & $8.3-12.8$ \\
\hline NDF (\%) & 54 & $74.7 \pm 2.3$ & $72.1-80.0$ & $75.0 \pm 2.1$ & $71.0-78.7$ & $75.2 \pm 2.1$ & $70.1-78.6$ \\
\hline $\operatorname{ADF}(\%)$ & 54 & $41.0 \pm 1.6$ & $37.7-43.6$ & $41.0 \pm 2.0$ & $37.0-44.2$ & $40.9 \pm 1.6$ & $37.7-43.2$ \\
\hline IVOMD (\%) & 54 & $54.9 \pm 4.0$ & $50.1-63.5$ & $55.5 \pm 4.6$ & $48.4-62.2$ & $55.5 \pm 4.2$ & $48.2-61.5$ \\
\hline Canopy height $(\mathrm{cm})$ & 54 & $71.7 \pm 13.1$ & $47.7-84.3$ & $75.2 \pm 14.5$ & $47.9-94.2$ & $75.8 \pm 13.8$ & $48.0-92.8$ \\
\hline FM (Ton ha $\left.{ }^{-1} \mathrm{DM}\right)$ & 54 & $3.4 \pm 0.4$ & $2.5-4.1$ & $3.6 \pm 0.5$ & $2.5-4.7$ & $3.9 \pm 0.7$ & $2.8-5.0$ \\
\hline LBM (Ton ha ${ }^{-1}$ DM) & 54 & $1.8 \pm 0.4$ & $0.9-2.5$ & $2.0 \pm 0.6$ & $0.8-2.8$ & $2.2 \pm 0.7$ & $0.8-3.2$ \\
\hline $\mathrm{SM}\left(\right.$ Ton $\left.\mathrm{ha}^{-1} \mathrm{DM}\right)$ & 54 & $0.6 \pm 0.1$ & $0.3-0.8$ & $0.8 \pm 0.2$ & $0.6-1.2$ & $0.9 \pm 0.2$ & $0.6-1.3$ \\
\hline SMM (Ton ha ${ }^{-1}$ DM) & 54 & $1.0 \pm 0.4$ & $0.4-2.0$ & $0.9 \pm 0.7$ & $0.2-2.4$ & $0.9 \pm 0.5$ & $0.2-2.2$ \\
\hline FAR $\left(\mathrm{kg} \mathrm{ha}^{-1}\right.$ day $\left.^{-1}\right)$ & 54 & $26.7 \pm 19.8$ & $-13.6-50.4$ & $36.3 \pm 27.4$ & $-7.1-76.7$ & $43.4 \pm 28.3$ & $-11.4-75.9$ \\
\hline $\mathrm{ADG}(\mathrm{kg} /$ day $)$ & 54 & $0.5 \pm 0.2$ & $0.2-0.8$ & $0.5 \pm 0.1$ & $0.2-0.7$ & $0.6 \pm 0.1$ & $0.2-0.6$ \\
\hline Stocking rate $\left(\mathrm{AU} \mathrm{ha} \mathrm{ha}^{-1}\right)^{*}$ & 54 & $2.7 \pm 0.7$ & $1.0-3.3$ & $3.1 \pm 1.0$ & $1.3-5.0$ & $4.0 \pm 1.3$ & $1.3-6.1$ \\
\hline
\end{tabular}

N: number of observations; OM: Organic matter; CP: Crude protein; NDF: Neutral detergent fiber; ADF: Acid detergent fiber; IVOMD: in vitro organic matter digestibility; FM: Forage mass; LBM: Leaf blade mass; SM: Stem mass; SMM: Senescent material mass; FAR:

Forage accumulation rate; ADG: Average daily gain. *Animal unit ( $1 \mathrm{AU}=450 \mathrm{~kg}$ live weight $)$.

Ciência Rural, v.51, n.1, 2021. 
Table 2 - Principal component analysis: standard deviation, proportion of variance explained by each component, cumulative variance and correlations between the principal components and the original variables.

\begin{tabular}{|c|c|c|c|}
\hline & $\mathrm{PC}_{1}$ & $\mathrm{PC}_{2}$ & $\mathrm{PC}_{3}$ \\
\hline Standard deviation & 3.428 & 1.116 & $6.215^{-14}$ \\
\hline Proportion & 0.900 & 0.096 & 0.004 \\
\hline \multirow[t]{2}{*}{ Cumulative variance } & 0.900 & 0.996 & 1.000 \\
\hline & \multicolumn{3}{|c|}{ - } \\
\hline Organic matter & 0.983 & -0.017 & -0.451 \\
\hline Crude protein & 0.992 & 0.048 & -0.445 \\
\hline Neutral detergent fiber & 0.999 & 0.134 & -0.434 \\
\hline Acid detergent fiber & -0.989 & -0.305 & 0.403 \\
\hline IVOMD & 0.952 & 0.014 & -0.456 \\
\hline Canopy height & 0.999 & 0.208 & -0.422 \\
\hline Forage mass & 0.999 & 0.161 & -0.430 \\
\hline Leaf blade mass & 0.999 & 0.208 & -0.422 \\
\hline Stem mass & 0.999 & 0.109 & -0.438 \\
\hline Senescent material mass & -0.999 & -0.194 & 0.425 \\
\hline Forage accumulation rate & 0.999 & 0.150 & -0.432 \\
\hline Average daily gain & 0.932 & 0.510 & -0.344 \\
\hline Stocking rate & 0.993 & 0.278 & -0.409 \\
\hline
\end{tabular}

IVOMD: in vitro organic matter digestibility.

accurate analysis (DA SILVA \& SBRISSIA, 2010; OLIVEIRA et al., 2019).

The first PC explained $90.0 \%$ of the data total variance. The significance of each variable can be observed by the correlation between the data correlation matrix and the component matrix (Table 2). For the first component, all variables contributed to the variance and were essential in the study; however, the structural variables were slightly more relevant (canopy height, forage mass (FM), leaf mass (LBM), stem mass (SM), forage accumulation rate (FAR)) and neutral detergent fiber (Table 2). The average daily gain was the most relevant variable in PC2; however, this PC explained less variance (9.6\%).

The results of the principal components (Table2) showed that the most relevant characteristics for the differentiation of Mombasa grass pastures under the effects of different residual nitrogen rates, in order of priority, were: forage accumulation rate, forage mass, leaf mass, stem mass, canopy height, and NDF (PC1). This single PC explains $90 \%$ of the data variance. The combination of these variables was probably related to the forage accumulation triggered by the residual effect of the highest rate of $\mathrm{N}(300 \mathrm{~kg}$ of $\mathrm{N})$.
As soil nitrogen becomes available, all photosynthetic processes are boosted, especially those related to leaf and tiller structure (PONTES et al., 2016), such as size, mass and appearance rate (BASSO et al., 2010) and population density (PITMAN, 2012). Thus, it results in higher forage accumulation rates (LOPES et al., 2013), forage mass (CANTO et al., 2013) and leaf mass (PONTES et al., 2016), which, in turn, increase the amount of forage available (FONTES et al., 2014).

The absence of variables related to the nutritional value of Mombasa grass among the variables of greater relevance, except for NDF, may be related to pasture management, especially regarding pre- and post-grazing height. In our study, pasture management was similar between treatments, which results in low fluctuation in the nutritional value of the leaves.

The first PC associated the structural variables of the pasture with the stocking rate. In the first PC, canopy height, FM, LBM and FAR were positively associated with stocking rate (Figure 1). This result was consistent with the pasture management since more animals are needed to maintain the post-grazing height targets $(40-50 \mathrm{~cm})$ as the forage production increases. 


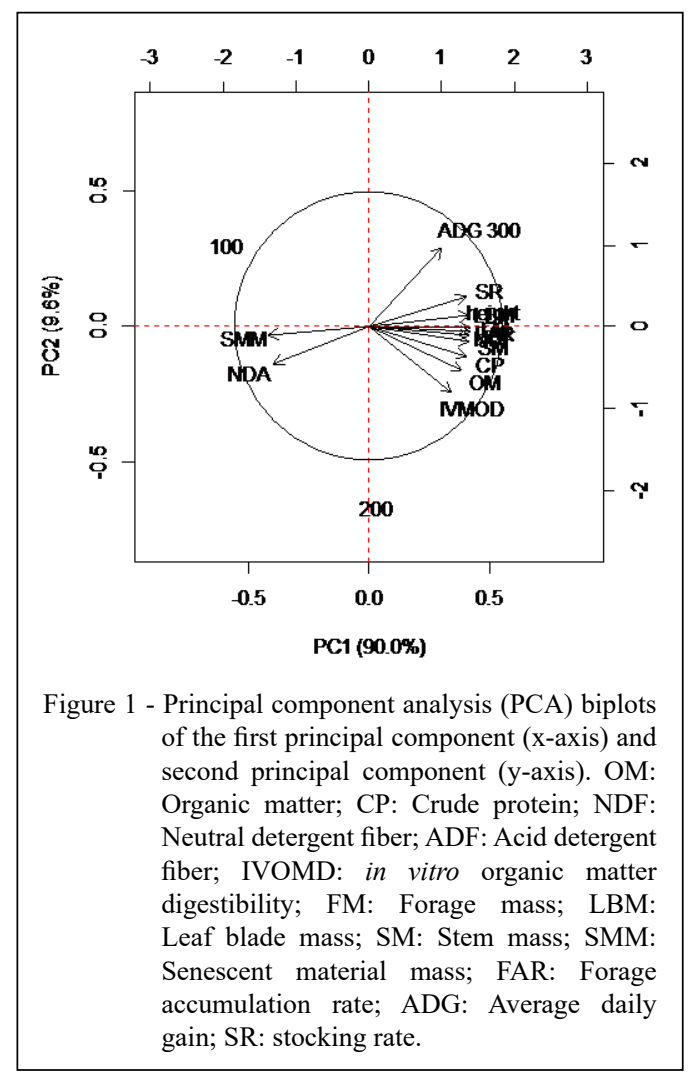

In the second $\mathrm{PC}$, which explained $9.6 \%$ of the data variance, SMM and ADF associated positively, while these and the other variables associated negatively with. This result indicated that cell content reduces and lignin deposition increases as the plant matures (GURGEL et al., 2017). It is important to highlight that the isolated effect of blocks and experimental period are not considered in the PCA.

The ADG was not associated with any variable (Figure 1), which may seem paradoxical, since pastures with higher forage and leaf blade masses should promote increased individual performance, and in fact, pastures under residual effect of $300 \mathrm{~kg}$ of $\mathrm{N}$ promoted higher ADG (Table 1). However, this difference was not significant when analyzed by univariate analysis (GURGEL, 2019).

This response was associated with pasture management since the stocking rate adjustments performed made the pre- and post-grazing canopy heights similar (GURGEL, 2019), indicating that the animals accessed a similar grazing horizon (ALVARENGA et al., 2020). When the canopy structure is not very distinct, adjustments in the forage search and apprehension processes are enough to guarantee maximum intake rate (CARVALHO, 2013). In animal production systems that use forage as a primary source of nutrients, intake is the variable that most interferes with animal performance (DIFANTE et al., 2010; MONTAGNER et al., 2013; EUCLIDES et al., 2015; EUCLIDES et al., 2017).

Results that demonstrated the effect of post-grazing height on the individual performance of animals were discussed by EUCLIDES et al. (2015 \& 2017) in Mombasa grass pastures, and by DIFANTE et al. (2010) in Tanzania grass pastures. In both experiments, the grazing management using an intermittent stocking rate with a pre-grazing target of $95 \%$ canopy light interception allowed the animals to explore different forage extracts. Conversely, some reports showed similarities in ADG and differences in weight gain per area of cattle in pastures managed under the same conditions of frequency and intensity of grazing (similar extracts) and fertilized with different nitrogen rates (RIBEIRO et al., 2011; MOREIRA et al., 2011; LUPATINI et al., 2013).

This information allowed us to affirm that in pastures managed with similar frequency and intensity of grazing between treatments, as is the case of experiments that evaluate nitrogen rates, gain per area (result of multiplying the stocking rate by the ADG) and the rate of stocking are more efficient parameters to support decision-making than the average daily gain, as they are more influenced by forage production.

\section{CONCLUSION}

The average daily gain and stocking rate are affected by residual nitrogen effects in Mombasa grass pastures. However, these oscillations are not mainly due to changes in the pasture nutritional value but are better explained by structural characteristics. The stocking rate is an efficient parameter to support decision-making in pastures managed with variable stocking rate and allow keeping a similar pasture structure between treatments. PC has the potential to be applied in the interpretation of data on forage plants.

\section{ACKNOWLEDGEMENTS}

The Coordenação de Aperfeiçoamento de Pessoal de Nível Superior (CAPES) for the financial incentive -Financing Code 001. Support from the Universidade Federal de Mato Grosso do Sul (UFMS), Conselho Nacional de Desenvolvimento Científico e Tecnológico (CNPq), Embrapa Gado de Corte and the Universidade Federal do Rio Grande do Norte (UFRN). 


\section{DECLARATION OF CONFLICTS OF INTERESTS}

The authors declare no conflict of interest. The founding sponsors had no role in the design of the study; in the collection, analyses, or interpretation of data; in the writing of the manuscript, and in the decision to publish the results.

\section{AUTHORS' CONTRIBUTIONS}

All authors contributed equally for the conception and writing of the manuscript. All authors critically revised the manuscript and approved of the final version.

\section{REFERENCES}

ALVARENGA, C. A. F. et al. Animal performance and sward characteristics of Mombaça guineagrass pastures subjected to two grazing frequencies. Tropical Grasslands-Forrajes Tropicales, v.8, n.1, p.1-10, 2020. Available from: $<$ http://dx.doi. org/10.17138/TGFT(8)1-10>. Accessed: Mar. 20, 2020. doi: 10.17138/TGFT(8)1-10.

BASSO, K. C. et al. Morphogenesis and tillering dynamics of Panicum maximum Jacq. cv. Tanzânia-I under grazing. Revista Brasileira de Saúde e Produção Animal, v.11, n.4, p.976-989, 2010. Available from: <http://www.rbspa.ufba.br/index.php/rbspa/ article/viewFile/1787/1024>. Accessed: Mar. 10, 2020.

BERNARDI, A. et al. Meta-analytic study of response of nitrogen fertilization on perennial summer grasses. Arquivos Brasileiro de Medicina Veterinária e Zootecnia, v.70, n.2, p.545-553, 2018. Available from: <http://dx.doi.org/10.1590/1678-4162-9501>. Accessed: Mar. 10, 2020. doi: 10.1590/1678-4162-9501.

CANTO, M. W. et al. Sward characteristics and agronomic efficiency of nitrogen on Tanzania grass under continuous grazing fertilized with nitrogen levels. Ciência Rural, v.43, n.1, p.682688, 2013. Available from: < http://dx.doi.org/10.1590/S010384782013000400019>. Accessed: Mar. 22, 2020. doi: 10.1590/ S0103-84782013000400019.

CARVALHO, P. C. F. Harry Stobbs Memorial Lecture: Can grazing behavior support innovations in grassland management. Tropical Grasslands-Forrajes Tropicales, v.1, n.2, 137-155, 2013. Available from: $<$ http://dx.doi.org/10.17138/TGFT(1)137155. Accessed: Mar. 25, 2020. doi: 10.17138/TGFT(1)137-155.

CASTAGNARA, D. D. et al. Nutritional value and structural characteristics of tropical grasses under nitrogen fertilization. Archivos de Zootecnia, v.60, n.232, p.931-942, 2011. Available from: $\quad<$ http://dx.doi.org/10.4321/S0004-05922011000400010>. Accessed:Mar. 18,2020. doi: 10.4321/S0004-05922011000400010.

DA SILVA, S. C.; SBRISSIA, A. F. Principal component analysis between morphogenetic and structural characteristics of Marandu palisadegrass swards under continuous stocking. Ciência Rural, v.40, n.3, p.690-693, 2010. Available from: <http://dx.doi. org/10.1590/S0103-84782010000300034>. Accessed: Mar. 25, 2020. doi: 10.1590/S0103-84782010000300034.

DIFANTE, G. S. et al. Performance and feed conversion of beef cattle steers on Tanzania guineagrass under two grazing intensities and rotational stocking. Revista Brasileira de Zootecnia, v.39, n.1, p.33-41, 2010. Available from: <http://dx.doi.org/10.1590/ S1516-35982010000100005>. Accessed: Mar. 04, 2020. doi: 10.1590/S1516-35982010000100005.

EMERENCIANO NETO, J. V. et al. Forage quality and performance of sheep in Massai grass pastures managed at pregrazing canopy heights. South African Journal of Animal Science, v.48, n.6, p.1073-1081, 2018. Available from: <http:// dx.doi.org/10.4314/sajas.v48i6.10>. Accessed: Mar. 09, 2020. doi: 10.4314/sajas.v48i6.10.

EMBRAPA - Centro Nacional de Pesquisa de Solos. Sistema Brasileiro de Classificação de Solos (3nd ed.). Rio de Janeiro, 2013. Available from: <https:/www.embrapa.br/busca-depublicacoes/-/publicacao/1094003/sistema-brasileiro-declassificacao-de-solos>. Accessed: Dec. 12, 2018.

EUCLIDES, V. B. P. et al. Maintaining post-grazing sward height of Panicum maximum (cv. Mombaça) at $50 \mathrm{~cm}$ led to higher animal performance compared with postgrazing height of $30 \mathrm{~cm}$. Grass and Forage Science, v.73, n.6, p.174-182, 2017. Available from: $<$ http://dx.doi.org/10.1111/gfs.12292>. Accessed: Jan. 15, 2020. doi: $10.1111 /$ gfs.12292.

EUCLIDES, V. P. B. et al. Steer performance on Panicum maximum (cv. Mombaça) pastures under two grazing intensities. Animal Production Science, v.56, n.11, p.1849-1856, 2015. Available from: $<\mathrm{http}$ ://dx.doi.org/10.1071/AN14721>. Accessed: Jan. 16, 2020. doi: 10.1071/AN14721.

FERNANDES, L. S. et al. Performance of sheep grazing Panicum maximum cv. Massai and supplemented with protein sources during the dry season. South African Journal of Animal Science, v.50, n.1, p.1-8, 2020. Available from: $<$ http://dx.doi.org/10.4314/sajas. v50i1.1>. Accessed: May, 18, 2020. doi: 10.4314/sajas.v50i1.1.

FONTES, J. G. G. et al. Herbage accumulation in Brachiaria brizantha cultivars submitted to defoliation intensities. Semina Ciências Agrarias, v.35, n.3, p.1425-1438, 2014. Available from: $<$ http://dx.doi.org/10.5433/1679-0359.2014v35n3p1425>. Accessed: Mar. 23, 2020. doi: 10.5433/1679-0359.2014v35n3p1425.

GURGEL, A. L. C. Interação solo-planta-animal em pastos de capim-mombaça sob efeito residual do nitrogênio. 2019. $57 \mathrm{f}$. Dissertação (Mestrado em Produção Animal) - Curso de Pósgraduação em Produção Animal, Universidade Federal do Rio Grande do Norte.

GURGEL, A. L. C. et al. Estrutura do pasto e desempenho de ovinos em capim-massai na época seca em resposta ao manejo do período das águas. Boletim de Industria Animal, v.74, n.2, p.86-95, 2017. Available from: <http://dx.doi.org/10.17523/bia. v74n2p86>. Accessed: Jan. 01, 2020. doi:10.17523/bia.v74n2p86.

LOPES, M. N. et al. Biomass flow in massai grass fertilized with nitrogen under intermittent stocking grazing with sheep. Revista Brasileira de Zootecnia, v.42, n.1, 13-21, 2013. Available from: <http://dx.doi.org/10.1590/S151635982013000100003>. Accessed: Mar. 05, 2020. doi: 10.1590/ S1516-35982013000100003.

LUPATINI, G. C. et al. Beef cattle production on black oats and Italian ryegrass pasture under nitrogen fertilization. Ciência Animal Brasileira, v.14, n.2, p.164-171, 2013. Available from: $<$ http://dx.doi.org/10.5216/cab.v14i2.21068>. Accessed: Mar. 26, 2020. doi: 10.5216/cab.v14i2.21068. 
MONTAGNER, D. B. et al. Dry matter intake by beef steers on Piatã palisadegrass (Brachiaria brizantha $c v$.BRS Piatã) pasture Tropical Grasslands - Forrajes Tropicales, v.1, n.1, p.106-108, 2013. Available from: <http://dx.doi.org/10.17138/TGFT(1)106108>. Accessed: Mar. 13, 2020. doi: 10.17138/TGFT(1)106-108.

MOREIRA, L. M. et al. Animal production on nitrogen fertilized signalgrass pasture. Arquivo Brasileiro de Medicina Veterinária e Zootecnia, v.63, n.4, p.914-921, 2011. Available from: <http:// dx.doi.org/10.1590/S0102-09352011000400017>. Accessed: Mar. 11, 2020. doi: 10.1590/S0102-0935201100040001.7.

OLIVEIRA, S. N. et al. Multivariate analysis using morphometric and ultrasound information for selection of tilapia (Oreochromis niloticus) breeders. Revista Brasileira de Zootecnia, v.48, n.1, e20170179, 2019. Available from: <http://dx.doi.org/10.1590/ S0102-0935201100040001.7>. Accessed: Mar. 06, 2020. doi: $10.1590 / \mathrm{rbz} 4820170179$.

PETERSEN, R. G.; LUCAS JUNIOR, H.L. Computing methods for the evaluation of pastures by means of animal response. Agronomy Journal, v.60, n.6, p.682-687, 1968. Available from: $<$ http://dx.doi.org/10.2134/agronj1968.00021962006000060031x>.
Accessed: Oct. 06, 2018. doi: 10.2134/agronj1968.00021962006 $000060031 \mathrm{x}$.

PITMAN, W. D. Bahiagrass (Paspalum notatum Flugge) management combining nitrogen fertilizer rate and defoliation frequency to enhance forage production efficiency. Grass and Forage Science, v.68, n.1, p.479-484, 2012. Available from: $<$ http://dx.doi.org/10.1111/gfs.12005>. Accessed: Oct. 30, 2019. doi:10.1111/gfs.12005.

PONTES, L, S. et al. Effects of nitrogen fertilization and cutting intensity on the agronomic performance of warm-season grasses. Grass and Forage Science, v.72, n.1, p.663-675, 2016. Available from: <http://dx.doi.org/10.1111/gfs.12267>. Accessed: Oct. 15, 2019. doi: $10.1111 /$ gfs. 12267 .

R CORE TEAM. R: A language and environment for statistical computing. R Foundation for Statistical Computing, Vienna, 2017. Available from: <https://www.R-project.org/>.

RIBEIRO, O. L. et al. Performance of beef cattle grazing Tanzania grass fertilized with nitrogen or intercropped with Stylo. Revista Brasileira de Saúde e Produção Animal, v.12, n.1, p.275-285, 2011. Available from: <http://revistas.ufba.br/index.php/rbspa/ article/viewArticle/1864>. Accessed: Mar. 27, 2020. 